City University of New York (CUNY) CUNY Academic Works

2008

\title{
Rousseau, the Anticosmopolitan?
}

Helena Rosenblatt

CUNY Graduate Center

\section{How does access to this work benefit you? Let us know!}

Follow this and additional works at: http://academicworks.cuny.edu/gc_pubs

Part of the French and Francophone Literature Commons, History of Philosophy Commons, and the Intellectual History Commons

\section{Recommended Citation}

Rosenblatt, Helena. "Rousseau the anti-Cosmopolitan." Daedalus vol. 137 No 3 (Summer 2008) : 59-67

This Article is brought to you by CUNY Academic Works. It has been accepted for inclusion in Publications and Research by an authorized administrator of CUNY Academic Works. For more information, please contact AcademicWorks@gc.cuny.edu. 


\section{Helena Rosenblatt}

\section{Rousseau, the anticosmopolitan?}

A complex and paradoxical thinker, Rousseau has rightly been called "the great wrecker of theories and categories." 1 This description is particularly fitting when it comes to cosmopolitanism, an ideal and a constellation of values that he repeatedly denounced. On this issue, as on so many others, Rousseau was both a philosophe and an antiphilosophe; his was a critique of the Enlightenment from within. ${ }^{2}$ Rousseau attacked cosmopolitanism not because he did not espouse the humanitarian principles it was supposed to promote, but because he thought it was a sham.

Setting himself up as the moral conscience of his age, Rousseau reminded his readers that manners and morals are not the same thing. Curiosity or 'openness' toward others, the willingness to do business with them, and even the eagerness to socialize with them should

Helena Rosenblatt is professor of history at Hunter College and the Graduate Center of The City University of New York. She is the author of "Rousseau and Geneva: From the First Discourse to the Social Contract, 1749-1762" (1997) and the forthcoming "Liberal Values: Benjamin Constant and the Politics of Religion."

(C) 2008 by the American Academy of Arts $\&$ Sciences not be confused with accepting them as one's social and political equals. As Rousseau pointed out, cosmopolitanism could, and did, easily coexist with, and lend support to, unjust political and social regimes. In rejecting cosmopolitanism, Rousseau held up a mirror to the elites of his time. He denounced what he thought were their superficial and selfcongratulatory attitudes. He revealed how unnatural, vain, and even corrupting their 'civilized' values were. With all their celebrated hospitality toward strangers and inquisitiveness about foreigners, cosmopolitan philosophes were neglecting a simple moral imperative: "The essential thing is to be good to the people with whom one lives."3

1 Arthur M. Melzer, The Natural Goodness of Man: On the System of Rousseau's Thought (Chicago: The University of Chicago Press, 1990), 283.

2 Mark Hulliung, The Autocritique of Enlightenment: Rousseau and the Philosophes (Cambridge, Mass. : Harvard University Press, 1994).

3 Unless otherwise indicated, all quotations from Rousseau are from his Oeuvres complètes, ed. Bernard Gagnebin and Marcel Raymond (Paris: Gallimard, Bibliothèque de la Pléiade, 1959-1995). (Henceforth, OC.) Translations are my own. This quotation is from Emile, oc, vol. IV, 249. 
Helena

Rosenblatt

on

cosmopoli-

tanism
Rousseau was not shy about his disdain for cosmopolitanism. In his political treatise, The Social Contract, he identified the cosmopolitan as a person who "pretended to love the whole world in order to have the right to love no one." 4 At the beginning of his pedagogical treatise, Emile, he placed a similarly cutting remark. Rousseau advised his readers to "beware of those cosmopolitans who go to great lengths in their books to discover duties they do not deign to fufill around them. A philosopher loves the Tartars so as to be spared having to love his neighbors." 5 Later in the same book, Rousseau again denounced cosmopolitan values as amounting only to hypocrisy and pretense: “The man of the world lives entirely in his mask.... What he really is, is nothing; what he appears to be is everything for him." 6

But these are only Rousseau's most obvious broadsides against cosmopolitanism. Elsewhere in his writings, he condemned the institutions and practices most commonly credited with spreading it: he denounced international commerce, regretted the progress of the sciences, detested cities, abhorred the salons, and violently objected to the "vile and deceitful uniformity" being propagated by cultural interaction. To Rousseau, the polite manners of "civilized people" were nothing but a hypocritical "veil" suffocating the inner voice of conscience; they were the "garlands of flowers" decorating the chains of despotism. ${ }^{7}$ One might even be tempted to say that all of Rousseau's literary pro-

4 Geneva Manuscript, OC, vol. III, 287.

5 Emile, 249.

6 Ibid., 515.

7 Discourse on the Sciences and the Arts, OC, vol. III, 3-4. ductions, from his autobiographical writings to his novels and political treatises, can be read as one long and elaborate diatribe against the rise of cosmopolitanism in early modern Europe.

In Rise of Cosmopolitanism in Early Modern Europe, Margaret Jacob celebrates the "border crossing" 8 encouraged by eighteenth-century cosmopolitans. Jacob argues that their tolerant attitude toward others promoted the transgression of boundaries separating people by nationality, race, class, religion, and gender. The cosmopolitans' openness toward people different from themselves, she reasons, eventually helped to spread the notion that all men are equal and in possession of the same human rights.

Given this compelling thesis, there is something strange and even disturbing about the fact that the most radically democratic thinker of his time, a man who even helped invent the term "rights of man," so vehemently disagreed. Indeed, much of Rousseau's philosophy is precisely about erecting barriers, keeping people apart, and even encouraging a certain amount of insularity. While cosmopolitans encouraged the " $\mathrm{min}$ gling, jostling, clubbing [and] fraternizing"9 that fostered communication and exchange between strangers, Rousseau preferred small and exclusive societies deliberately designed to keep out foreigners.

Thus, in his pedagogical treatise Emile, Rousseau advised parents to erect psychological walls around their children to shield them from the outside world,

8 Margaret Jacob, Strangers Nowhere in the World: The Rise of Cosmopolitanism in Early Modern Europe (Philadelphia: University of Pennsylvania Press, 2006), 4.

9 Ibid., 6. 
to "set up an enclosure around your child's soul." 10 Emile's education up to the age of twelve is expressly designed to avoid his exposure to, and thus eventual dependence on, other people. He is raised far from the city and kept away from the social relationships that Rousseau believed were inherently corrupting. Care is taken not to awaken his curiosity about other people or faraway places; he is not taught urbane manners. Rather, he is educated so as to preserve his natural goodness, to be self-sufficient and comfortable in nature, and to value the simple and solitary pleasures of the countryside.

Similarly, in his novel Julie, or the New Heloise, Rousseau constructed an ideal community especially designed to protect its inhabitants from the outside world. Clarens is a community that is as insular and secluded as it is small. It is isolated geographically and largely self-sufficient economically. Thus, it cultivates its members' psychological and material autonomy, which Rousseau suggests is the only way to true happiness. In a preface to the novel, Rousseau explained that one of his purposes in writing it was to teach men to "love solitude." He wanted them to leave the crowded cities and move to places where they could "hold some distance one from another." He hoped to teach them that "the sweetest sentiments of the heart," cultivated in carefully circumscribed and ordered communities like Clarens, were far more agreeable than all the "affected" socializing going on in the cosmopolitan cities. ${ }^{11}$

Rousseau's political writings also show his preference for small, isolated, and self-sufficient states whose economies

10 Emile, 246.

11 Julie, or the New Heloise, OC, vol. II, 21. center on agriculture, not trade. He repeatedly upheld ancient Rome and Sparta as models, warning his fellow Genevans to abandon their emerging commercial ethos and return to their traditional values. Rousseau's recommendations to both Poland and Corsica also called for strict regulation of their commerce. He advised them to encourage agriculture and a rustic life instead. If the Poles wished to create "a free, wise, and peaceful nation... self-sufficient and happy," they should "preserve and revive among [their] people simple customs and wholesome tastes." ${ }^{2}$ To Rousseau, trade with foreigners was not a civilizing or democratizing force; rather, it was a poisonous source of inequality and corruption. Commerce with others engendered the love of luxury and its related train of vices. It caused people to neglect their real duties and become selfish and vain.

$\mathrm{R}$ as the cultural conformity being promoted by commerce and travel. While eighteenth-century cosmopolitans displayed an eagerness to borrow ideas and habits from other lands or civilizations, Rousseau warned people against such practices. "Today," he wrote regretfully, "there are no longer Frenchmen, Germans, Spaniards, or even Englishmen; there are only Europeans. All have the same tastes, the same passions, and the same customs." 13

To counter what he saw as a nefarious trend, Rousseau advised states to cultivate what was unique about themselves. When forming a state, the first rule to follow was "national character." To the

12 Considerations on the Government of Poland, OC, vol. III, 1003.

13 Ibid., 960.
Rousseau, the anticosmopolitan? 
Helena Rosenblatt on cosmopolitanism
Corsicans, he explained, "Every people has or ought to have a national character and if it lacks one, we would have to begin by giving it one." 14 Likewise, to the Poles he spoke admiringly of "the genius, the character, the tastes and the mores of a people, that cause it to be itself and not another." 15 Such statements are partly why Rousseau is often regarded as a founder of modern nationalism.

One efficient way to cultivate national character was through patriotism. In the Discourse on Political Economy, Rousseau declared that every legitimate state should protect and encourage national institutions designed to attach its citizens to their country. It should offer civic education to its inhabitants and encourage traditional customs, ceremonies, festivals, and spectacles. Thus, Rousseau advised the Poles that they should encourage "that ardent love of country based upon habits of mind impossible to uproot." 16 And he suggested that each Corsican should be made to swear the following oath: "I unite my body, my goods with all my will and all my power to the Corsican nation. I swear to live and die for it." 17

Rousseau even seems to have accepted the fact that patriotism normally goes along with a contempt for foreigners. He noted that the ancients knew this; for them, the words 'stranger' and 'enemy' were synonymous. ${ }^{18}$ At the beginning of Emile, Rousseau acknowledges that

14 Project for a Corsican Constitution, OC, vol. III, 913.

15 Considerations on the Government of Poland, 960.

16 Ibid.

17 Project for a Corsican Constitution, 943.

18 Geneva Manuscript, 288. "every patriot is hard on strangers; they are only men, they are nothing in his eyes. This inconvenience is inevitable, but not serious." 19 Rousseau was not alone among eighteenth-century thinkers in perceiving a fundamental incompatibility between love of country and love of humanity. Voltaire explicitly distinguished between being a patriot and a "citizen of the world"; the cosmopoli$\tan$ Voltaire, however, favored the latter. Throughout history, patriotism had only consisted in "bringing back to the communal mob what one stole from other nations.... To love one's country thus means to kill and plunder other men." Elsewhere, Voltaire wrote that "to wish for the greatness of one's country is to wish evil to one's neighbors." 20 But Rousseau thought otherwise. Throughout his writings, he attacked cosmopolitanism, extolled patriotism, and proudly trumpeted his own title: "citizen of Geneva."

Thinking about Geneva seems to have been particularly conducive to stimulating Rousseau's mistrust of strangers and foreigners. In his "Dedication" to the Second Discourse, he denounced the values Genevans were acquiring while traveling abroad. He urged them to turn inward and cultivate their patriotism instead. In Julie, or the New Heloise, a main character explains that "the Genevan gets his virtues from himself; his vices come from elsewhere." 21 Again, in his Letter to d'Alembert, Rousseau wrote, "Never has a foreigner entered Geneva,

19 Emile, 248.

20 As quoted by Thomas J. Schlereth, The Cosmopolitan Ideal in Enlightenment Thought: Its Form and Function in the Ideas of Franklin, Hume and Voltaire, 1694 - 1790 (Notre Dame, Ind. : University of Notre Dame Press, 1977), 207.

21 Julie, or the New Heloise, 662. 
but that he has done more harm than good." 22 To Rousseau, strangers and foreigners were dangerous; they infected wholesome communities with corrupt values.

$\mathrm{R}$ Rousseau himself was a solitary man by inclination, and felt awkward in society. Late in life he confessed, "I have never been truly suited for civil society, where everything is annoyance, obligation, and duty ... my independent natural temperament always made me incapable of the subjection necessary to anyone who wants to live among men." 23 Nevertheless, his autobiography recounts some fleeting moments of happiness experienced as a young man in what Rousseau described as an intimate "little circle," centered on Madame de Warens: "All our vows, our cares, our hearts were in common," he recalled. "Nothing of them passed outside of the little circle." 24 Here again, then, one sees Rousseau's preference for the closed, intimate, and secluded communities that he felt were the only spaces within which sincere communication between human beings could occur.

Later, of course, he identified himself as a "citizen of Geneva," and tried to be a true patriot by advising his fellow Genevans on how to protect their traditions and constitution. ${ }^{25}$ In this attempt he largely failed; few Genevans under-

22 Letter to d'Alembert, ed. Michel Launay (Paris: Éditions due Seuil, 1967), 243.

23 The Reveries of the Solitary Walker, OC, vol. I, 1059.

24 Confessions, OC, vol. I, 201.

25 Helena Rosenblatt, Rousseau and Geneva (Cambridge: Cambridge University Press, 1997). stood the Second Discourse, and The Social Contract was condemned in Geneva as it was elsewhere in Europe: few of his fellow Genevans rose up in his defense. Thus, he gave up his Genevan citizenship and ended up spending much of his life alone, as a social and political outcast. Late in life, he developed acute feelings of paranoia.

No wonder, then, that Rousseau's later writings, particularly the autobiographical ones, promote an ethic of withdrawal and inwardness. In The Reveries of the Solitary Walker, he speaks of his intense desire for solitude, and his conviction that "the source of true happiness is within us." 26 Indeed, by writing highly personal texts, such as Confessions, Rousseau: Judge of Jean-Jacques, and The Reveries, Rousseau valorized introspection and man's private inner world. In a different way, Rousseau's late botanical writings helped to spread the idea that the best life is spent not in the company of other human beings, but in solitary communion with nature. From start to finish, then, Rousseau seems to have lived the life, and espoused the values, of an anticosmopolitan.

\section{$\mathrm{B}$ he didn't also contradict himself. Thus he sometimes spoke well of cosmopoli- tanism. In the Discourse on the Origin of Inequality, he praised the "great Cosmo- politan Souls" who resisted particularist or nationalist sentiments and "embraced all of mankind in their benevolence." 27 In the Discourse on the Sciences and the Arts, he similarly celebrated those philoso- phers, such as Bacon, Descartes, and Newton, who distinguished themselves}

26 The Reveries of the Solitary Walker, 1003.

27 Discourse on the Origins of Inequality, OC, vol. III, 178.
Rousseau, the anticosmopolitan? 
Helena

Rosenblatt

on

cosmopoli-

tanism by being "tutors of mankind." 28 In his own writings, Rousseau claimed to adopt "a language that suits all Nations," and to promote the "felicity of mankind." 29 By these contradictory statements, what he seems to be saying is not that all cosmopolitanism is bad, but that true cosmopolitanism is rare.

Moreover, although Rousseau is sometimes called a founder of modern nationalism, it would certainly be wrong to equate Rousseau's endorsement of "national character" and patriotism with the virulent nationalism born later, in the nineteenth century. First, it is important to realize that patriotism, in Rousseau's thought, is always closely linked with political liberty. Rousseau believed that only free men could be moved to love their fellow citizens, "for it is only they who have a common existence and are truly linked together by the law." To Rousseau, patriotism did not come from the love of a specific geographic area, but rather from that of a particular set of laws; democratic principles and patriotism were inextricably linked. Only "a true republican" who is also a "member of the sovereign" could experience "the love of the fatherland, that is, its laws and its liberty." 30 Thus, there is not necessarily a contradiction between Rousseau's stance on 'national character' and patriotism, and the underlying humanitarian principles of cosmopolitanism.

Second, Rousseau denounced all systems of rule based on domination, exploitation, or even dependence, and he made his horror of war and violence

28 Discourse on the Sciences and the Arts, 20, my emphasis.

29 Discourse on the Origin of Inequality, 133.

30 Considerations on the Government of Poland, 966. abundantly clear. Even more to the point: in the Second Discourse, Rousseau regretted the moment in history when "the division of mankind into different societies" had occurred. The unity of humanity had been lost irretrievably and, with the division of the species, had come

National Wars, Battles, murders and reprisals that make nature tremble and shock reason, and all those horrible prejudices that rank among the virtues the honor of shedding human blood. The most decent people learned to consider it among their duties to kill their fellow men. Finally, men were seen massacring one another by the thousands without knowing why. ${ }^{31}$

It was after making this statement that Rousseau referred to the few "great Cosmopolitan Souls" who managed to rise above national divisions.

Finally, Rousseau himself exhibited a kind of cosmopolitanism when he, far ahead of his time, identified and denounced what he saw as Eurocentrism in European travel accounts. In a revealing footnote to the Second Discourse, he regretted that Europeans did not have accurate information about other cultures. Travel accounts were infected by "ridiculous" "national prejudices." 32 Once again, Rousseau's point was that, under present circumstances, true cosmopolitanism was rare. Instead, what you had were many civilized hypocrites who pretended to love the world while, in fact, loving only themselves.

The truth is that despite Rousseau's professed preference for close-knit families, private "circles," and small city-

31 Discourse on the Origin of Inequality, 178.

32 Ibid., 213. 
states like Geneva, he was deeply attached to universalist and humanitarian principles. As I already noted, in the First Discourse, his critique of Enlightenment values was intended to promote the "felicity of mankind." In the Second Discourse, his denunciation of society had a similarly humanitarian goal: "It is of man that I am to speak," he wrote, "I shall defend with confidence the cause of humanity."

Rousseau was especially eager to convince people that even though present society was corrupt, and political states unjust, man was born "naturally good." Human nature was therefore not to blame for man's sorry predicament. Moreover, Rousseau was keen to show that human nature was everywhere the same. All men, regardless of class, race, nationality, or religion, had a common ancestor (the "noble savage"); and all men were endowed by their maker with the same basic human qualities. They were "perfectible," that is, capable of self-improvement and endowed with a free will. Notably, all men, regardless of origin, shared an instinct of compassion - which Rousseau held to be the source of all "sentiments of humanity." Over the course of history, a combination of factors had led human beings to suppress their natural capacity for compassion, which had stunted their "sentiments of humanity." 33

The problems of the world were therefore not the result of a flawed human nature; rather, in the Second Discourse, Rousseau explained how men had been corrupted through a fundamentally vicious socialization process. A series of historical accidents and unfortunate choices had turned the noble savage into modern man: a civilized hypocrite, who, under a veil of cosmopolitan politeness,

33 Ibid., 37, 55 . was actually selfish, competitive, and vain. Clearly, then, society's problems could not be solved simply by accelerating the pace of social interaction, as the cosmopolitan ideal seemed to suggest. There was something profoundly wrong with the way modern men related to each other. Deeper changes were needed than "mingling, jostling, [and] clubbing" with strangers.

Anyone who reads Rousseau attentively will soon see that his preference for small, enclosed communities sheltered from the outside world was not about withdrawal for withdrawal's sake. Always a moralist, Rousseau thought deeply about how to socialize men properlyin other words, how to reactivate man's instinct of compassion and to cultivate those "sentiments of humanity" that are latent in each individual.

In this sense, Emile can even be read as a book about the formation of a true cosmopolitan. Rousseau began by dismissing the notion that Emile should be raised as a patriotic citizen. He declared that "there is no longer a fatherland," and thus the word "citizen" should be "erased from modern languages." 34 Hence the young boy is not taught national character or patriotism. He is raised to be a "man" rather than a "citizen." Kept away from cities and society while he is young and impressionable, he is prevented from acquiring corrupt tastes such as the desire to please or to dominate others. Instead, he is given an education in conformity with nature, designed precisely to foster his sentiments of humanity. He is then taught to "generalize" and "extend" his compassion to "the whole of mankind." 35 All of this prepares him for adulthood, when

34 Emile, 250.

35 Ibid., 253
Rousseau, the anticosmopolitan? 
Helena Rosenblatt on cosmopolitanism he will be well equipped to enter into healthy social relations with others. As a finishing touch to Emile's education, he is advised to take long trips abroad, which will allow him to get to know other peoples. A free spirit, unencumbered by national prejudice, the adult Emile spends almost two years choosing where to live, only to conclude that "I shall loosen all the bonds which attach me to [wealth] .... Rich or poor, I shall be free. I shall not be free in this or that country, in this or that region. I shall be free everywhere on earth." Elsewhere, Emile remarks: "What does it matter where I am? Wherever there are men I am among my brothers." 36

As all of his writings make clear, Rousseau believed in peace, justice, and mutual understanding. He wished to promote sincere bonds of affection between human beings, and to encourage their naturally latent "sentiments of humanity." The real question for him was how to accomplish this. How was one to draw modern individuals, who are prone to selfishness and vanity, out of themselves and into a fruitful and moral engagement with others? Rousseau believed that it could only be done on a small, local scale. Only carefully circumscribed and controlled communities like Clarens, Madame de Warens's "little circle," or tiny city-states like Geneva, could socialize individuals effectively. Human beings needed to turn inward, to consult their consciences, to listen to their natural sentiments, and thus find their true and shared humanity, before they could love others as they loved themselves.

For Rousseau, it was primarily the family, and the family with a loving woman at its center, that could socialize the individual, teaching him sincere feelings of affection for others. Genuine so-

36 Ibid., $856-857$. cialization could certainly not happen in a cosmopolitan city. Being suddenly thrown together with masses of strangers does not moralize the individual; rather, it encourages false display and thereby even estranges man from himself. This can be seen in the character Saint-Preux in Julie, or the New Heloise. Visiting Paris, Saint-Preux soon remarks, "It is the first inconvenience of great cities that men become different from what they really are, and that society gives them, so as to speak, a different being than their own." 37 To Julie, he explains, "I enter with a secret horror into this vast desert of the world. This chaos offers only a horrible solitude where a dismal silence reigns." He remembers an ancient writer who once said, "I am never less alone than when I am alone"; after experiencing Paris, Saint-Preux adds, "I am alone only when in a crowd." 38

Something very different happens to Saint-Preux in Clarens, where honesty and transparency reign. Within their protected "little world," members of the household can reveal their feelings to each other openly and thus remain true to themselves. Crucially, Rousseau suggests that the sincere ties of affection that are nurtured in a place like Clarens can be extended outward to the world beyond. In one particularly suggestive passage, Saint-Preux describes the emotions he had felt one day, right before a holiday celebration was about to begin: he had been moved by the "agreeable and touching portrait of communal happiness, which seemed at that moment to cover the face of the earth." 39 Experiencing compassion and affection within a do-

37 Julie, or the New Heloise, 273.

38 Ibid., 231.

39 Ibid., 17, 604, my emphasis. 
mestic community allows the individual to expand and extend these sentiments to encompass the rest of the world.

In his political writings, Rousseau suggests that there is a similar dynamic at work in international relations. Human beings do not automatically identify and sympathize with people who are different from themselves, who live far away, and about whom they know little. In the Discourse on Political Economy, he explains, "It seems that the sentiment of humanity evaporates and weakens as it extends itself across the globe." To activate man's latent sentiments of humanity, it is necessary to "limit and compress" his natural feelings of compassion, focusing them first on his fellow citizens, before they can be extended further. ${ }^{\circ}$ As Rousseau writes elsewhere, "We conceive of the general society on the basis of our particular societies; the establishment of small republics makes us think about the large one, and we only really begin to become men after having been citizens." 41 Once again, then, Rousseau's praise of patriotism and national character is not incompatible with true cosmopolitanism; rather, he suggests that the right kind of patriotism, nurtured in a small republic like Geneva, would be conducive to it.

E ven in his lonely seclusion during his final years, as Rousseau became more and more reclusive and introspective, he never abandoned his essentially universalist and humanitarian outlook. In his autobiography, Confessions, he reached across all barriers constructed by society in order to speak directly to his readers. He bared his soul and, in so doing, invited his readers to recognize their own hu-

40 Discourse on Political Economy, OC, vol. III, 254 .

41 Geneva Manuscript, 287. manity in his. Once again, Rousseau suggested that it was only by withdrawing from society - in other words, by removing oneself from all the social sources of falsehood and hypocrisy - that one could discover one's true self; and only then could one identify humanely with others. And, once more, his intensely personal writing helped to develop sympathetic understanding in his readers, enabling them to empathize across class, sex, and national lines.

Rousseau's last major work, The Reveries of the Solitary Walker, begun in 1776 and still unfinished at the time of his death, reflects his final descent into what most scholars now recognize was paranoia. In its opening passage, he describes his complete estrangement from society: "Here I am, then, alone in the world, with no brother, neighbor, or friend, nor any company left to me but my own." "Everything external is henceforth foreign to me," he continues, "I am on earth as though on a foreign planet....Alone, for the rest of my life...I find consolation, hope, and peace only in myself." However, in a final jab at the Enlightenment's version of cosmopolitanism, Rousseau suggests that even as a hermit, he is a greater lover of mankind than any fashionable socialite could ever be. Withdrawn from society, he can get in touch with his true nature and thus the sources of his humanity. "I love myself too much to hate anyone at all. That would be to compress my existence, and I would instead like to extend it across the whole universe." 42 In this paradoxical way, by removing himself from society, and by being a stranger everywhere in the world, Rousseau proffered lessons to all of mankind and even offered himself as the 'truest' cosmopolitan of them all.

42 The Reveries of the Solitary Walker, 995, 999, 106.
Rousseau, the anticosmopolitan? 